\title{
Lacrimal Gland Carcinoma Pathologic Distant Metastasis TNM Finding v8
}

National Cancer Institute

\section{Source}

National Cancer Institute. Lacrimal Gland Carcinoma Pathologic Distant Metastasis TNM

Finding v8. NCI Thesaurus. Code C140779.

A pathologic finding about one or more characteristics of lacrimal gland carcinoma,

following the rules of the TNM AJCC V8 classification system as they pertain to distant metastases. 